\title{
Статьи
}

Пространственная Экономика

2021. Том 17. № 3. С. 38-58

JEL: C02, D73, I26, F60

https://dx.doi.org/10.14530/se.2021.3.038-058

УДК $330+339$

\section{Traditional Values and Institutional Quality}

\author{
N. Berk, N. Madmarov
}

Necati Berk

Postgraduate Student

National Research University Higher School of Economics, Doctoral School of Economics, 11 Pokrovsky Bulvar, Moscow, 101000, Russian Federation

E-mail: necatiberk34@gmail.com; nberk@hse.ru

ORCID: 0000-0002-8267-1662

\section{Nurbek Madmarov}

Postgraduate Student

Kyrgyz-Turkish Manas University, Institute of Social Sciences, 56 Mira Avenue, Bishkek, 720044, Kyrgyzstan

E-mail: nurbekmadmarov17@gmail.com

ORCID: 0000-0002-2329-5433

Abstract. Why do similar economic and political institutions function differently in various cultures? This paper tries to identify potentially important factors related to the institutional quality. We investigate the relationship between cultures, cultural dimensions: non-tradition in particular, and formal institutions to explain differences in the quality of institutions around the world. We use a measure of traditional values, structured by Inglehart and Baker, from the World Values Survey, to extend the literature on the determinants of institutions' quality. We show that differences in traditional values are suggestive to explain differences in the quality of institutions across countries. The OLS method is utilized in order to analyze the factors of institutional quality in sixty countries in 2010-2014. In this study, the OLS models are employed in order to understand the key factors of institutional differences among countries in the period of 2010-2014. The empirical model results show that (i) non-tradition is a reliable significant variable with positive contributions on six institutional quality variables, (ii) urbanization has unexpected negative effects on some institutional quality indicators like rule of law, political stability and voice/accountability. However, it has meaningful contribution to control of corruption in the countries, (iii) economic development have increasing impacts on the majority of the institutional quality variables, (iv) while education has positive effects on government effectiveness, political stability and regulation quality, it has negative unexpected impacts on rule of law and voice/accountability, (v) openness has only effects on corruption and political stability, (vi) there are non-linear relationships between dependent variable(s) and independent variables rather than linear relationships.

Keywords: culture, institutions, economic development, tradition, traditional values, institutional quality

For citation: Berk N., Madmarov N. Traditional Values and Institutional Quality. Prostranstvennaya Ekonomika = Spatial Economics, 2021, vol. 17, no. 3, pp. 38-58. https:// dx.doi.org/10.14530/se.2021.3.038-058

(C) Berk N., Madmarov N., 2021 


\section{Траgиционные ценности и качество институтов}

\section{H. Бepk, H. Magmapoв}

\section{Берк Неджати аспирант}

Национальный исследовательский университет «Высшая школа экономики», Аспирантская школа по экономике, Покровский бульвар, 11, Москва, 101000, Российская Федерация E-mail: necatiberk34@gmail.com; nberk@hse.ru

ORCID: 0000-0002-8267-1662

\section{Мадмаров Нурбек}

аспирант

Кыргызско-Турецкий Университет «Манас», Институт социальных наук, Проспект Мира, 56, Бишкек, 720044, Кыргызстан

E-mail: nurbekmadmarov17@gmail.com

ORCID: 0000-0002-2329-5433

Аннотация. Почему похожие экономические и политические институты по-разному функционируют в разных культурах? В данной работе осуществляется попытка определить потенциально важные факторы, влияющие на качество институтов. Авторы рассматривают взаимосвязь культуры, культурных изменений, в частности нетрадиционализма, и официальных институтов с целью объяснить различия в качестве институтов по всему миру. В работе используется измерение традиционных ценностей Инглхарта и Бейкера из базы World Values Survey (WVS) для более глубокого понимания детерминант качества институтов. Для анализа факторов, влияющих на качество институтов на основе информационного массива по шестидесяти странам за 2010-2014 гг. используется метод наименьших квадратов. Результаты модели показывают, что культура и экономическое развитие являются наиболее надежными факторами институционального качества институтов в шестидесяти странах. Результаты эмпирической модели показывают, что (i) отсутствие традиций является надежной значимой переменной с положительным вкладом в шесть переменных качества институтов; (ii) урбанизация оказывает негативное влияние на некоторые показатели качества институтов, такие как верховенство закона, политическая стабильность и голос / подотчетность; (iii) экономическое развитие оказывает все большее влияние на большинство переменных институционального качества; (iv) образование положительно влияет на эффективность правительства, политическую стабильность и качество регулирования, оно оказывает неожиданное негативное влияние на верховенство закона и право голоса / подотчетность; (v) открытость влияет только на коррупцию и политическую стабильность; (vi) существуют нелинейные отношения между зависимыми переменными и независимыми переменными, а не линейные отношения.

Ключевые слова: культура, институты, экономическое развитие, традиция, традиционные ценности, качество институтов

Для цичтирования: Berk N., Madmarov N. Traditional Values and Institutional Quality. Prostranstvennaya Ekonomika = Spatial Economics. 2021. Vol. 17. No. 3. Pp. 38-58. https:// dx.doi.org/10.14530/se.2021.3.038-058 


\section{INTRODUCTION}

Interdisciplinary studies in economics have again received increasing attention among those interested in the differences in incomes and institutional quality among countries and regions (Tabellini, 2008; Tabellini, 2010; Gorodnichenko, Roland, 2010; Gorodnichenko, Roland, 2012; Gorodnichenko, Roland, 2013; Alesina, Giuliano, 2013, Alesina, Giuliano, 2015; Roland, 2016a). The early scholars such as Smith and Weber tried to analyze the cultural effects on economic performance in order to explain the disparities between rich and poor nations. Specifically, preliminary studies of Weber can be considered to be the birth of cultural economics. In his seminal book of 1905, Weber argues that religion, in particular Protestant ethic, is the main force behind differences in economic outcomes due to its stress on work ethic. In short, we might say that Weber was the first scholar who claimed that culture played an important role in explaining prosperities of countries (Weber, 1930).

However, after the intense use of mathematics and econometrical tools in economic analysis, economists (neoclassical in particular) have avoided investigating topics that were vague and difficult to quantify such as culture. Various definitions of culture can be found inside and outside the field of economics. The absence of a widespread recognized global definition, consequently, made most economists hesitate to rely on culture and its relationship with economic outcomes. Lack of international data, also, have made it difficult to measure cultural differences for examining effects of culture on economic performance and institutional quality for the cross-country approach.

In recent decades, some economists contributed immensely in their effort to define the notion of culture. For example, Guiso et al. (Guiso et al., 2006) define culture as 'those customary beliefs and values that ethnic, religious, and social groups transmit fairly unchanged from generation to generation'. Alesina and Giuliano (Alesina, Giuliano, 2015) claim that this definition is used in the most research papers in the economic literature. International datasets such as the World Values survey and the General Social Survey, since 1980s, have made it possible to measure the cultural values and beliefs and use them in the economic analysis (Roland, 2016a).

A considerable body of literature on cultural economics has developed in the last couple of decades. Economists have examined the casual relationship between specific cultural aspects (trust, respect, responsibility, obedience, family ties, and individualism-collectivism), institutions, and economic attitudes in various empirical studies (Alesina, La Ferrara, 2002; Guiso et al., 2004; Algan, Cahuc, 2010; Algan, Cahuc, 2014; Borisova et al., 2017). Nonetheless, scholars have not reached a wide consensus on how cultural variables and institutions relate to and evolve in, and influence on economic performance. 
Cultural economists select a set of variables, mainly related to trust, from the World Value Survey. However, they did not pay enough attention to the following variable which is much closer to the definition of culture used by most economists. 'Tradition is important to this person; to follow the customs handed down by one's religion or family'. One of the primary reasons why economist did not pay sufficient attention to the variable is because it was introduced in the World Value Survey on the fifth wave. In other words, the first four surveys did not include the variable. Second, previous studies have almost exclusively focused on trust, social capital, and individualistic-collectivistic dimension. The variable is crucial because it is more appropriate to measure the effects of religion or parents to the later generation's thinking patterns and preferences. This can reveal us those who follow or value their ancestors' customs or religion without questioning much. Could traditionalism be a barrier for progress? It depends on what a society has inherited from the previous generations. If the previous generation follow the law and the rules, respect the human rights and are open to innovation, they encourage the next generation to follow their path.

This paper tries to explore the relationship between cultural dimensions: nontradition, and formal institutions to explain differences in the quality of institutions. One of the contributions of this work is that we combine two cultural frameworks to create our own 'non-tradition index' based on some variables from the survey. Our technique is, initially introduced by Inglehart and Baker (Inglehart, Baker 2000), similar to the way proposed by Alesina and Giuliano (Alesina, Giuliano, 2013), but we measure the non-tradition instead of family ties. We show that differences in traditional values is suggestive to explain differences in the quality of institutions across countries. The limitation of examining of the impact of culture on institutional quality is that it also influences culture. We attempt to go above the general argument that culture is important. We illustrate that culture is one of the determinants of institutional differences; however, we do not aim to claim any exact answer to the issue of causality.

The rest of the paper is structured as follows. We review previous studies that has discussed the association between cultural variables and institutions' quality in the next section. This is followed by a brief description of data, how we chose our variables, and we present and analyze the main findings. We then conclude the paper.

\section{LITERATURE REVIEW}

Scholars in social sciences have been interested in exploring the role of cultural diversity across countries. Culture is one of the most critical determinants for forming the interests, beliefs, and values of a person, which in turn directly and indirectly influences economic outcomes. Lately, the relationship between 
culture, institutions, and economic performance has been shown to be robust by economists. A great deal of economic activities are determined by various cultural factors (Alesina, Giuliano, 2015; Rose, 2015; Roland, 2016b). Some researchers have reported the effects of particular cultural indicators such as responsibility, obedience, respect, and individualism-collectivism dimension (Hofstede, 2001; Hofstede et al., 2010) which impact economic behaviors and institutions over time. Largely, one of the cultural variables most examined in economic analysis to date is trust (Alesina, La Ferrara, 2002; Guiso et al., 2004; Alesina, Angeletos, 2005; Algan, Cahuc, 2010; Algan, Cahuc, 2014; Algan et al., 2016; Borisova et al., 2017).

It is from the end of $20^{\text {th }}$ century, the idea that 'poor-quality' institutions are one of the key factors behind the underperforming economy of emerging countries has been a broad consensus (North, 1990; Acemoglu et al., 2001, Acemoglu et al., 2002, Acemoglu et al., 2006; Glaeser et al., 2004; Rodrick et al., 2004; Chang, 2011.). New institutionalists claim that the variation of economic development is explained by the varying quality of institutions across countries. This argument could be justified from the findings of prominent economists (Acemoglu et al., 2001; Acemoglu et al., 2006; Dollar, Kraay, 2003; Rodrick et al. 2004) who focus on examining the potential linkage between formal institutions and economic development. Although new institutionalists have made a substantial contribution to the effects of institutions on the economic outcomes, the factors affecting formal institutions have been still insufficiently investigated within the currently dominant discourse on institutions in the economic literature.

Various empirical research have been proposed to show the underlying causes of institutional differences. For example, the accumulation of human capital and rise in income are the driving force behind institutional development (Glaeser et al., 2004), strong family ties are the key reasons behind the 'low-performing' institutions (Alesina, Giuliano, 2013), a causal positive relationship between a sound tax system and institutional quality (Alonso, Garcimartin, 2013), as well as trade openness impact on institutions' quality positively and significantly (Islam, Montenegro, 2002), the influences of legal origin on institutional improvement (Chong, Zanforlin, 2000; Straub 2000), how openness impacts on corruption (Wei, 2000), the association between ethnic diversity and quality of institutions (La Porta et al., 1999), the effects of particular institutions such as strong check and balances, and a free media on overall institutional quality (Djankov et al., 2001), and the effect of family dynamics on the creation of public pension systems (Galasso, Profeta, 2012).

What seems to be clear at first glance is that researchers have come to conflicting findings in identifying the underlying causes of institutional quality. La Porta et al. (La Porta et al., 1999) argue that ethnic diversity is correlated with 'lower' 
institutional quality. This is inconsistent with the view of Islam and Montenegro (Islam, Montenegro, 2002). They claim ethnic heterogeneity has no association with quality of institutions. Alonso and Garcimartin (Alonso, Garcimartin, 2013) claim that openness is not associated with institutional quality, in contrast to what has been found previously. There are several explanations why certain results might appear to contradict each other. First, the number and the selection of countries differ from one another. For example, when some scholars use large datasets, it has been observed that the importance of some factors in affecting quality of institutions disappear. Second, empirical studies cover countries at a different stage of development, as a result, the conclusion of the authors differ from one another. Finally, the available proxies for institutional quality is different such as World Bank Governance Indicators and the International Country Risk Guide.

Acemoglu et al. (Acemoglu et al., 2001; Acemoglu et al., 2006; Acemoglu, Robinson, 2012) highlight the importance of political power for economic and political institutions. They argue that neither culture nor geography affect economic outcomes or institutional quality. They claim that there is a linear relationship between formal institutions and culture in which formal institutions impacts the culture. Nevertheless; North (North, 1990; North, 2005), Platteau (Platteau, 2000), Aoki (Aoki, 2001), Boettke and Leeson (Boettke et al., 2008), and Tabellini (Tabellini, 2008; Tabellini, 2010) draw attention to that informal institutions such as norms, customs, values and beliefs might prevent formal institutions functioning effectively and informal institutions might shape the structure of formal institutions. More recently, a growing body of research, Alesina and Giuliano (Alesina, Giuliano, 2015), Bisin and Verdier (Bisin, Verdier, 2015), Roland (Roland, 2016b), stresses that culture and institutions have a twoway connection with each other and evolve mutually impacting one another. Few scholars, Rose (Rose, 2015), claim that culture matters most and shapes all formal institutions since those institutions rely on a cultural foundation.

Acemoglu etc. al. claim that the mechanism affecting institutional quality is political system held by 'elites' who have the ultimate power. 'Elites' are the most crucial factors behind the 'poor-quality' institutions in underdeveloped and emerging countries. In other words, they argue that 'elites' affect formal institutions negatively through its impact on political system. Furthermore, some institutionalists build a relationship from institutions to culture. For example, Cassar, d'Adda, and Grosjen (Cassar et al., 2014) have tried to determine the causal impact of institutional quality on social capital such as trust and trustworthiness, and to better understand the relationship between quality of institutions and cultural variables as well as how that relationship can sustain economic exchange. For this purpose, they run an experiment consisting of 346 subjects from Kosovo, northern and southern Italy. Their results reveal that 
there is a positive correlation between an impartial legal enforcement system and social trust and trustworthiness in which contract enforcement affect social capital. They maintain that their findings imply that moral norms of cooperative behaviour may emerge as a by-product of impartial formal institutions. They also claim that opportunistic behaviours can be affected by cultural background, initial trust, and trustworthiness when impartial legal institutions are absent in the markets. Nevertheless, they argue that legal enforcement can be replaced by trust in the markets when formal institutions are absent. Similarly, their results suggest that trust may offset the adverse effects of the lack of impartial institutions in society. Last but not least, they believe the existence of a unilateral association between formal and informal institutions in which economic institutions influence culture and offset the mutual feedback between institutions and culture.

Some economists have published on the impact of specific cultural traits on the formal institutions and economic behaviors. For instance, Kyriacou (Kyriacou, 2015) has attempted to measure the effect of the individualistcollectivist dimension on the quality of government (the rule of law and property rights are secured by states and public administration works effectively without corruption) and investigates how the interaction between this cultural trait and the quality of government matters for development economics. The result shows that individualism has a positive causal effect on long-term growth since individualism creates better governance (formal institutions). Gorodnichenko and Roland (Gorodnichenko, Roland, 2015) go a step further and claim that the origins of democracy have been due to the variations in the aspect of the individualism-collectivism dimension across the world. They develop a simple model based on the idea that the individualist-collectivist cleavage is a profound determinant of democratization. A crucial distinction between these cultural traits is that a collectivist society generates a higher pressure towards conformity and more resistance to radical institutional change. They present that individualistic cultures tend to adopt democracy faster than collectivistic cultures, having the same level of autocracy at the beginning, even though collectivist culture could be better at solving collective action problems. Therefore, scholars claim that collectivism can often cause democratic failure in societies. In other words, they point out that collectivism can be a cause and an indicator of democratic instability in societies. Furthermore, they also show that collectivism often leads to having a 'better' autocracy instead of democracy, while it is the other way around in individualistic societies. They conclude that their finding was due to the higher resistance for radical institutional changes in collectivist societies. However, Bisin and Verdier (Bisin, Verdier, 2017) argue that culture and institutions have a two-way connection with each other. They are endogenous and determined mutually. They impact on not only economic development and wealth but also 
all kind of economic activities. Alesina and Giuliano (Alesina, Giuliano, 2015); Roland (Roland, 2016a) also state that culture and institutions interact jointly and complement each other.

Tabellini also explores the interaction between cultural variables on the one hand, institutions, and economic performance, on the other. Tabellini (Tabellini, 2010) find empirical evidence that formal institutions function differently in regions within countries, in particular some regions of Europen Union. $\mathrm{He}$ points out that some formal institutions such as judicial system in Southern and Northern Italy have been identical over 150 years since the rules for becoming a judge and the legal system have been the same. However, making decisions about investigations and ruling on 'civil cases' take much longer time in Southern Italy compare to Northern Italy. He stresses that some scholars documents similar evidence in the working of public administrations and schools much less efficient in Southern Italy. He argues that cultural variables: trust, respect for others, and control affect legal institutions positively even within countries. He emphasizes that those cultural traits impact on economic performance directly and indirectly through its impact on institutions. He also maintains that historical institutions affect culture and culture affects economic growth. For example, institutions of democratic systems of the U.S. immigrants countries of origin, influence their general morality positively even in third generation. If they come from a despotically ruled country, their limited morality is much higher. Specific cultural traits such as trust and respect increase quality of institutions (Tabellini, 2008).

Boettke et al. point out that we cannot consider all institutions the same. Hence, they broadly separate and categorize institutions in three groups: 'foreign-introduced exogenous institutions', 'indigenously introduced exogenous institutions' and 'indigenously introduced endogenous institutions' which 'stickiness' increases respectively. They call institutions as indigenously introduced if they are mainly planned by insiders and as foreign introduced if those are mainly planned by outsiders. They call institutions as exogenous if they are founded and implemented by authority. They stress that values, beliefs, and customs are crucial for formal institutions operating in the desired way. If an institution is spontaneously established, it complies with customs, norms, values and beliefs of the society. They call such institutions as 'indigenously introduced endogenous institutions' and they are the stickiest institutions. On the other hand, they claim that 'foreign-introduced exogenous institutions' are the least sticky since they do not much comply with customs, beliefs, and values. Therefore, such institutions are more likely to fail in many countries.

Simply put, culture is primarily handed down from past generations to future generations. As a result, previous generations play a vital role in influencing the thinking patterns, interests, beliefs, ideas, and values of the next generations. 
Political, legal, and social institutions are established by humankind. Thus, one can agree with Rose (Rose, 2015) that property rights and the rule of law rely on the institutional foundation, and such institutional foundations rely on a cultural base. Roland (Roland, 2016a) highlights that culture tends to shift gradually in comparison to formal institutions, which can shift dramatically. Both factors may be reason of the failure of foreign institutions in emerging countries. As Williamson (Williamson, 2009) states that formal institutions are only efficient and most effective when they comply with informal constraints. Hence, we can conclude that despite decades of research on cultural economics studies, the role of traditional values in the formation and functioning of formal institutions across countries remains not well explored in many ways.

\section{DATA, EMPIRICAL STRATEGY AND RESULTS}

A crucial question for our empirical analysis is how to measure culture and cultural variables. The most common way of measuring culture is using surveys. For measuring culture, we follow most economists (Tabellini, Roland, Alesina etc.) and use data from the World Values Surveys. The survey provides detail on the demographics, values, beliefs, and responses to specific questions such as happiness, religion, behaviors, and political views around the world. We measure non-tradition index by looking at six WVS variables from the sixth wave (WVS6 2010-014) of the survey: 'Tradition is important to this person; to follow the customs handed down by one's religion or family' which take values from 1 to 6 , 'it is important to this person to always behave properly; to avoid doing anything people would say is wrong' which also take values from 1 to 6 , 'one of my main goals in life has been to make my parents proud" which take values from 1 to 4, "important qualities that children can be encouraged to learn at home' that we consider those who choose 'religious faith' and 'obedience' which take values 1 or 2, and 'indicate how important religion is in your life' which take values from 1 to 4 . The values are normalized between 0 and 1 for each of these dimensions. We combined all the responses from the entire dataset with all individual answers to the initial questions and create our non-tradition index.

Inglehart (Inglehart, 1997) selected, initially, 22 variables from the World Value Surveys for measuring 'Traditional vs. Secular-Rational Values' dimension. However, he (Inglehart, Baker 2000) limited the number of items to ten to avoid problems of missing data. Schwartz (Schwartz, 1999; Schwartz, 2012), broadly, identifies ten different types of human values. One of the 10 broad basic values is tradition which he defines 'respect, commitment, and acceptance of the customs and ideas that one's culture or religion provides'. He measures the tradition based on the following variable 'tradition is important to this person; to follow the 
customs handed down by one's religion or family'. The previous variable is our main indicator for measuring non-tradition index. We chose three variables which is related with our main indicator among ten items for Inglehart's dimensions. Schwartz (Schwartz, 2012) also emphasizes that tradition and conformity values are closely linked. Therefore, we include conformity variable as well.

Lastly, this research combines two cultural frameworks for the classification of non-tradition index. They are; the cultural context of Inglehart and the cultural framework of Schwartz. According to Inglehart and Baker (Inglehart, Baker, 2000), traditional society values stress 'importance of God in someone life', 'children should be taught obedience and faith at home', and 'one of my main goals in life has been to make my parents proud'. Schwartz highlight the key elements of conservatism: 'conformity' and 'tradition following the customs and ideas handed down by one's religion or family'. We create non-tradition index by looking at six WVS variables which combines those two cultural frameworks.

The non-tradition index is generated in 4 steps: (i) the values of six variables below 1 are dropped as these are missing data or these include the codes for persons who did not want to respond to the survey questions, (ii) all values of the variables are normalized into the range $[0,1]$ by using the formula $z V_{i}=\frac{V_{i}-\min .\left\{V_{i}\right\}}{\max \cdot\left\{V_{i}\right\}} \mathrm{i}=$ 9 for V9-'indicate how important religion is in your life', 19 for V19-'Important qualities that children can be encouraged to learn at home: religious faith' etc., (iii) then the normalized values are merged by using the formula $N T=\frac{\sum f_{i} *_{z} V_{i}}{\sum f_{i}}$ where $f_{i}$ denotes for the weights of persons who respond below 3 if the maximum response value is 6 , below 2 if the maximum response value is 4 , and below 1 if the maximum response value is 2 in questions $V_{i}$ for $\mathrm{i}=9,19,21,49,77,79$, (iv) the individual responses of persons in the countries are aggregated for the relevant country levels by using collapse mean ... command in Stata.

We use the World Governance Indicators (WGI) of the World Bank as a measure of institutional quality. The WGI focuses on six broad indicators of governance: rule of law (the efficiency of property rights, contract enforcement and the court etc.), voice and accountability (freedom of the speech and the media etc.), political stability and absence of violence (the state would not be weakened or removed from power by unlawful or violent means etc.), government effectiveness (the quality of civil service and public services etc.), regulatory quality (the ability of the state to design and enforce effective regulation and policies), and control of corruption for more than 200 countries for the period 1996-2019. Each of the indicators of governance takes value approximately between -2.5 and 2.5 . As the values in these indicators approach to -2.5 , a country gets weaker in the 
institutional quality. However, when the values approach to +2.5 , a country gets stronger in the institutional quality.

Regarding the macroeconomic determinants of institutional quality, firstly Glaser et al. (Glaser et al., 2004) and Chang (Chang, 2011) argue that economic wealth leads to 'better-quality' institutions. Alonso and Garcimartin (Alonso, Garcimartin, 2013) shows that education is one of the underlying causes of the institutional quality. However, the impact of education on institutional quality might have a threshold. Once a nation reaches the threshold, the level of education can no longer increase the quality of institutions further. Islam and Montenegro (Islam, Montenegro, 2002) find that trade openness impact on institutions' quality positively and significantly.

Then the above empirical studies suggest that the set of independent variables to explain the institutional quality may consist of variables like GDP and/or GDP per capita as the main determinant, and openness, urban population, human capital etc. Then the basic model for this study for each country i can be as the following:

$$
I Q_{i}=\beta_{0}+\beta_{1} N T_{i}+\beta_{2} Y_{i}+\beta_{3} \text { Open }_{i}+\beta_{4} \operatorname{Urban}_{i}+\beta_{5} E_{d u c_{i}}+u_{i}
$$

where $I Q$ is the institutional quality represented by the six World Bank WGI indicators like rule of law etc., $N T$ is the combined measure or index of culture by the authors, $Y$ is the economic development represented by the real GDP per capita, Open is the openness indicator represented by the sum exports and imports of goods and services as a percentage of GDP, Urban is the percentage of urban population to total population, Educ is the proportion of adult population aged 15 years and above that is literate, and $u$ is the error term. All independent variables, except $N T$, are transformed into natural logarithms in order to avoid from high volatility and multicollinearity problem (Wooldridge, 2016, pp. 171-173).

The model in (i) will be estimated via OLS method and it is assumed to satisfy all six classical linear model (CLM) assumptions (Wooldridge, 2016, pp. 105-108). However, these assumptions should be tested in order to determine whether the OLS estimators from (i) satisfy CLM assumptions; the model specifically should be tested for assumptions MLR. 4 'Zero Conditional Mean', 5 'Homoscedastic Variance of Error Term', and 6 'Normality of Error Term' (Wooldridge, 2016, pp. 275-279 and 250-254; Jarque, Bera, 1981). If any problem like functional form misspecification and/or heteroskedasticity appears in a regression model, they will be eliminated. Then in the regression model, firstly the model with the independent variables in the linear form will be given, then if needed the model with better functional form like the model with squares and interaction terms and/ or cubes, and the model with Huber-White standard errors will be estimated.

The data set is collected from the World Values Surveys $6^{\text {th }}$ wave, the World Bank World Development Indicators and the World Governance Indicators. The 
period for the macro data ranges from 2010 to 2014 based on the realization of the culture index NT; that is to say, if the data for NT takes place in 2010, then the data for all other independent variables and the dependent variable in that year (2010) is utilized as well and etc. Table 1 shows these different years for the model countries. The NT values are calculated by using the World Values Surveys $6^{\text {th }}$ wave data as this dataset gives the highest number of countries. Lastly, it is believed that culture or NT is stable or very sticky over time (Roland, 2016a).

Table 1

The corresponding periods for the culture index and macro variables for model countries

\begin{tabular}{l|c|c}
\hline \multicolumn{1}{c|}{ Country } & $\begin{array}{c}\text { Period } \\
\text { for NT }\end{array}$ & $\begin{array}{c}\text { Period for the } \\
\text { Macroeconomic Variables }\end{array}$ \\
\hline Japan, Rep. of Korea, Qatar, Trinidad and Tobago & 2010 & 2010 \\
\hline $\begin{array}{l}\text { Armenia, Azerbaijan, Belarus, Cyprus, Estonia, Kazakhstan, } \\
\text { Kyrgyzstan, Morocco, New Zealand, Russia, Slovenia, Spain, } \\
\text { Sweden, Ukraine, U.S., Uruguay, Uzbekistan }\end{array}$ & 2011 & 2011 \\
\hline $\begin{array}{l}\text { Australia, Chile, Columbia, Egypt, Ghana, Malaysia, Mexico, } \\
\text { Netherlands, Nigeria, Pakistan, Peru, Philippines, Poland, } \\
\text { Romania, Rwanda, Singapore, Taiwan, Turkey, Zimbabwe }\end{array}$ & 2012 & 2012 \\
\hline $\begin{array}{l}\text { Argentina, Bahrain, China, Ecuador, Germany, Iraq, Lebanon, } \\
\text { Palestine, S. Africa, Thailand, Tunisia }\end{array}$ & 2013 & 2013 \\
\hline $\begin{array}{l}\text { Algeria, Brazil, Georgia, Hong Kong, India, Jordan, Kuwait, } \\
\text { Libya, Yemen }\end{array}$ & 2014 & 2014 \\
\hline
\end{tabular}

Source: WVS6 and World Bank data.

The hypotheses tests for the model (i) can be written as the following:

H1: The more the society becomes non-traditional, the more qualified will be the formal institutions.

It should be noted that as $N T$ increases, a society in a country becomes more non-traditional, and as $I Q$ increases to +2.5 , the country's formal institutions become stronger. Then more liberal societies lead to the formal institutions to be stronger and more advanced.

H2: The more developed a country gets, the more qualified will get the formal institutions.

Most of the studies above suggest that there is a causality from economic development to institutional quality.

H3: The more a country gets open in trade with other countries, the more qualified will be the formal institutions.

It should be noted that when the country gets more open to trade, its economy definitely benefits from these and, it, in turn, leads to stronger institutions.

H4: The more the society gets urbanized, the more qualified will get the formal institutions. 
Urbanization actually brings new opportunities for a new labor force and this may in turn contribute to the local economy. Thus, it will be beneficial for the institutions after some time.

H5: The greater number of people in a country gets educated, the more qualified will be the formal institutions.

As people become more educated, they can contribute to the domestic production more, and thus institutional quality advances.

Now let us give the empirical model results. Let us start with the figures of non-tradition index versus the institutional quality (rule of law and corruption):

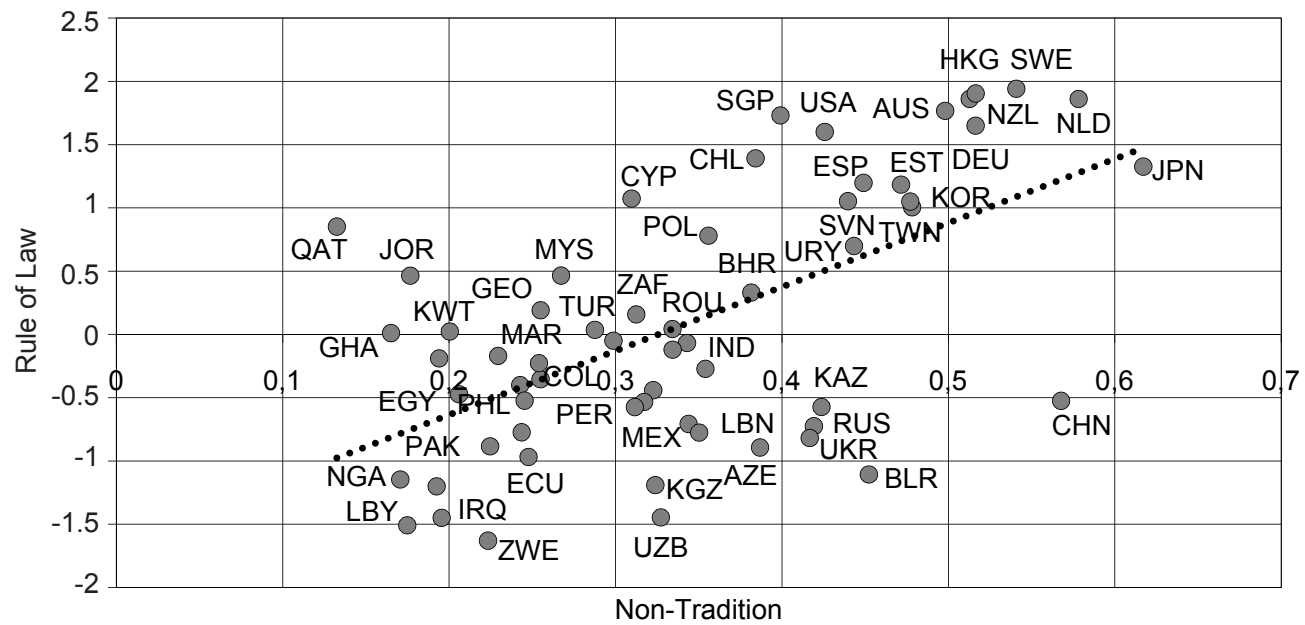

Fig. 1. Non-tradition and rule of law, 60 countries, 2010-2014

Source: The authors' own graph by using WVS6 and World Bank data.

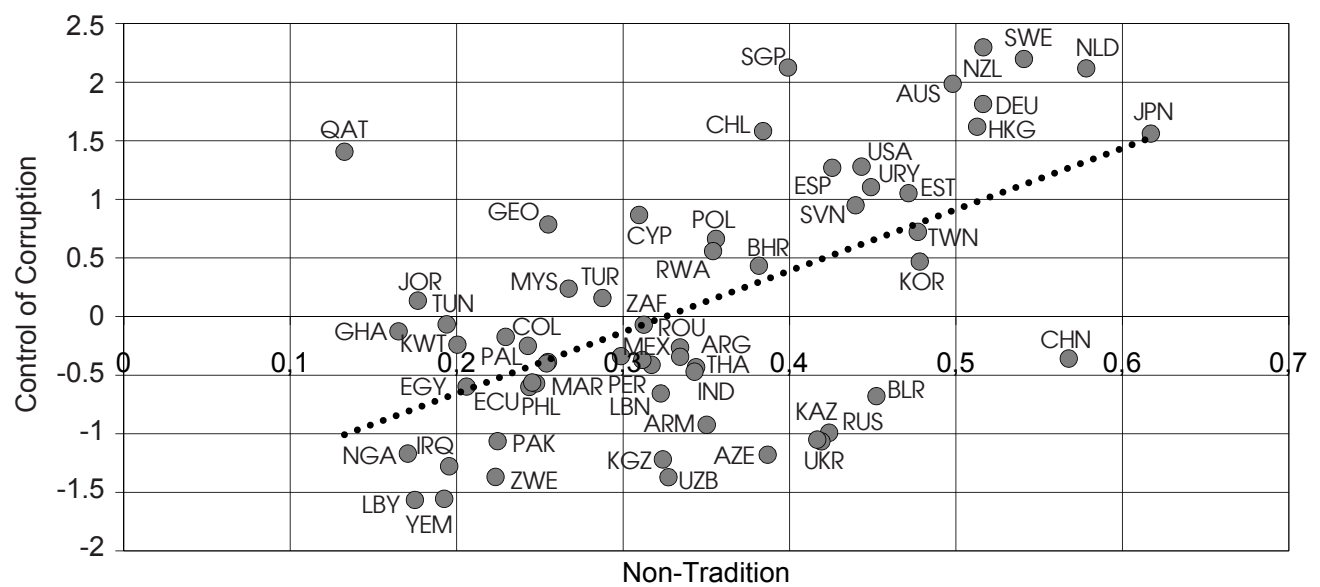

Fig. 2. Non-tradition and control of corruption, 60 countries, 2010-2014

Source: The authors' own graph by using WVS6 and World Bank data. 
In figure 1 and 2, we plot rule of law and control of corruption respectively against our main indicator of the cultural variable: non-tradition. Both figures show a positive connection between non-tradition variable and quality of institutions. This is consistent with the idea that some cultural variables such as non-tradition might improve institutional quality. However it is also possible that formal institutions might impact on cultural variables such as trust (Tabellini, 2010), religion, and individualism (Kyriacou, 2015). Our purpose is to show that non-tradition is positively and strongly related to institutional quality without giving any exact answer to the issue of causality.

Similarly, the correlations between the institutional quality and independent variables are calculated as the following:

Correlation coefficients among institutional quality

Table 2 indicators and independent variables

\begin{tabular}{|c|c|}
\hline Institutional Quality Indicator & Independent Variables and Correlations \\
\hline Rule of law (rolaw) & $\begin{array}{c}\mathrm{Y}(0.79 * * *), \mathrm{NT}(0.596 * * *), \text { Open }(0.258 * *), \\
\operatorname{Urban}(0.485 * * *), \text { Educ }(0.404 * * *)\end{array}$ \\
\hline Control of corruption (corruption) & $\begin{array}{c}\mathrm{Y}(0.767 * * *), \mathrm{NT}\left(0.581^{* * *}\right), \text { Open }\left(0.226^{*}\right), \\
\text { Urban }\left(0.466^{* * *}\right), \text { Educ }(0.394 * *)\end{array}$ \\
\hline Government effectiveness (goveffect) & $\begin{array}{c}\mathrm{Y}(0.783 * * *), \mathrm{NT}\left(0.615^{* * *}\right), \text { Open }\left(0.248^{*}\right) \\
\text { Urban }(0.478 * * *), \text { Educ }\left(0.466^{* * *}\right)\end{array}$ \\
\hline $\begin{array}{l}\text { Political stability and absence of violence } \\
\text { (polstability) }\end{array}$ & $\begin{array}{c}\mathrm{Y}(0.702 * * *), \mathrm{NT}(0.604 * * *), \text { Open }\left(0.235^{*}\right) \\
\text { Urban }(0.437 * * *), \text { Educ }\left(0.588^{* * *}\right)\end{array}$ \\
\hline Regulatory quality (regulation) & $\begin{array}{c}\mathrm{Y}\left(0.718^{* * *}\right), \mathrm{NT}(0.572 * * *), \text { Open }\left(0.251^{*}\right), \\
\text { Urban }\left(0.435^{* * *}\right), \text { Educ }\left(0.438^{* * *}\right)\end{array}$ \\
\hline Voice and accountability (voice) & $\begin{array}{c}\mathrm{Y}\left(0.638^{* * *}\right), \mathrm{NT}(0.499 * * *), \text { Open }(0.0016), \\
\text { Urban }\left(0.388^{* * *}\right), \text { Educ }\left(0.35^{* * *}\right)\end{array}$ \\
\hline
\end{tabular}

Note: $* * *$ and $* * *$ shows significance at $10 \%, 5 \%$ and $1 \%$ levels.

Source: Authors own calculations by using Stata.

Economic development is highly correlated with the institutional quality variables. While the non-tradition and urban have mild correlations, education quality has low linear correlation with the institutional quality indicators. The low correlation is the case between openness and the institutional quality variables.

Now, it is time to determine the factors of institutional quality variables. So, the regression models for the dependent variables are as the following.

According to Table 3 results, the factors of rule of law show that there are nonlinear relationships between rule of law and its determinants ( $p$-value of Ramsey RESET test is very low).

Then the regression model with non-linear factors on rule of law can be interpreted as (i) holding all other variables fixed, every 1 standard deviation increase of nontradition leads to a 1.42 points increase in rule of law (ii) holding all other variables 
fixed, every $1 \%$ increase in urbanization leads rule of law to decrease by 0.00596 standard deviation, (iii) while there is increasing effects with increasing rate (convex relationship) of economic development on rule of law is the case, there is decreasing effects with increasing rate of education on rule of law exists.

Indicators of institutional quality, 2010-2014

Table 3

\begin{tabular}{|c|c|c|c|c|}
\hline & \multicolumn{4}{|c|}{ Dependent Variable } \\
\hline & \multicolumn{2}{|c|}{ Rolaw } & \multicolumn{2}{|c|}{ Corruption } \\
\hline \multirow{6}{*}{$\begin{array}{l}\text { Linear } \\
\text { variables }\end{array}$} & $C:-3.076$ & 16.047 & -3.184 & $13.426^{*}$ \\
\hline & Y: $0.785^{* * *}$ & & $0.812 * * *$ & \\
\hline & NT: $1.778^{* *}$ & $99.477 * *[1.42]$ & $1.84 *$ & $88.802 *[1.64]$ \\
\hline & Open: $0.253^{*}$ & & 0.213 & $-5.021 *[1.913 *]$ \\
\hline & Urban: $-0.666^{*}$ & $-15.381 *[-0.596 *]$ & -0.707 & $2.378 *[-19.638 * * *]$ \\
\hline & Educ: -0.704 & & -0.664 & \\
\hline $\begin{array}{l}\text { Interaction } \\
\text { variables }\end{array}$ & & $\begin{array}{c}\text { Y*Urban: }-0.873^{* *} \\
\text { Urban*Educ: } 5.107^{* *} \\
\text { Y*NT: } 1.801^{* * *} \\
\text { NT*Educ: }-25.523^{* * *} \\
\text { Open*Educ: } 0.072^{* * *}\end{array}$ & & $\begin{array}{l}\text { Y*Urban: }-1.528^{* *} \\
\text { NT*Urban: } 8.229^{* * *} \\
\text { NT*Educ: }-26.956^{* *} \\
\text { Open*Educ: } 1.538^{* *}\end{array}$ \\
\hline $\begin{array}{l}\text { Square } \\
\text { variables }\end{array}$ & & $\begin{array}{c}\text { Y2: } 0.201 * * \\
\text { Educ }^{2}:-1.64(0.135)\end{array}$ & & $\begin{array}{c}\text { Y2: } 0.378 * * * \\
\text { Open }{ }^{2}:-0.197 \\
(0.2043) \\
\text { Urban }^{2}: 2.238^{* * *}\end{array}$ \\
\hline $\begin{array}{l}\text { Additional } \\
\text { statistics }\end{array}$ & $\begin{array}{c}\mathrm{R}^{2}=0.708, \\
\text { Adj. } \mathrm{R}^{2}=0.681, \\
\text { Prob(F-stat. })= \\
0.000 \\
\end{array}$ & $\begin{array}{c}\mathrm{R}^{2}=0.8084 \\
\text { Adj. } \mathrm{R}^{2}=0.774 \\
\text { Prob(F-stat. })=0.000\end{array}$ & $\begin{array}{c}\mathrm{R}^{2}=0.663, \\
\text { Adj. } \mathrm{R}^{2}=0.632, \\
\text { Prob(F-stat.) }= \\
0.000 \\
\end{array}$ & $\begin{array}{c}\mathrm{R}^{2}=0.779 \\
\text { Adj. } \mathrm{R}^{2}=0.733 \\
\text { Prob(F-stat. })=0.000\end{array}$ \\
\hline $\begin{array}{l}\text { Diagnostic } \\
\text { test } \\
\text { statistics }\end{array}$ & \begin{tabular}{|c|} 
BPG Heteroske- \\
dacticity: $10.57^{*} ;$ \\
JB Normality: \\
0.088; Ramsey \\
RESET: $8.329 * * *$ \\
\end{tabular} & $\begin{array}{l}\text { BPG Heteroske- } \\
\text { dacticity: } 6.768 ; \mathrm{JB} \\
\text { Normality: } 0.118\end{array}$ & $\begin{array}{l}\text { BPG Heteroske- } \\
\text { dacticity: } 1.727 ; \\
\text { JB Normality: } \\
\text { 0.38; Ramsey } \\
\text { RESET: } 9.562 * * *\end{array}$ & $\begin{array}{c}\text { BPG Heteroske- } \\
\text { dacticity: } 12.937 \text {; } \\
\text { JB Normality: } 1.591\end{array}$ \\
\hline
\end{tabular}

Note: $*, * *$ and $* * *$ shows significance at $10 \%, 5 \%$ and $1 \%$ levels.

Source: Authors own calculations by using Stata.

Also, Table 3 shows that there are non-linear relationships between control of corruption (hereafter only corruption) and its determinants. Then the coefficients can be interpreted as (a) holding all other variables fixed, economic development has increasing effects of increasing rate on control of corruption, (b) holding all other variables fixed, openness has increasing effects with decreasing rate on control of corruption. The optimal level of openness, that yields maximum value of control of corruption, is $1.913 /(2 * 0.197)=$ 4.85533 or $((\text { Export }+ \text { Import }) / \mathrm{GDP})^{*}=128.423 \%$. The percentage of values of (Export+Import)/GDP, that are more than $123.423 \%$ are only $12 / 60 * 100=$ $20 \%$, (c) Urbanization has decreasing effects with increasing rate on control of 
corruption; that is to say, till $\log ($ urbanization $)=19.638 /(2 * 2.238)=4.3874$ or Urbanization $*=80.431 \%$ urbanization decreases control of corruption, then increases. The percentage of values of urbanization, that are more than $80.431 \%$ are only $18 / 60 * 100=30 \%$. Then the increasing effect of urbanization on control of corruption is only true for $30 \%$ of countries.

Indicators of institutional quality, 2010-2014

Table 4

\begin{tabular}{|c|c|c|c|}
\hline & \multicolumn{2}{|c|}{ Dependent Variable } & \\
\hline & \multicolumn{2}{|c|}{ Goveffect } & Polstability \\
\hline \multirow{6}{*}{ Linear variables } & C: $5.017 * *$ & -8.06 & $-12.158 * * *$ \\
\hline & Y: $0.71 * * *$ & $-1.79 *$ & $0.622 * * *$ \\
\hline & NT: $1.639 * *$ & $104.053 * * *[1.865 * *]$ & 1.467 \\
\hline & Open: $0.209^{*}$ & & 0.182 \\
\hline & Urban: $-0.727 * *$ & & $-0.935 * *$ \\
\hline & Educ: 0.024 & & $1.91 * *$ \\
\hline $\begin{array}{l}\text { Interaction } \\
\text { variables }\end{array}$ & & $\begin{array}{c}\text { Y*Open: } 0.021^{*} \\
\text { Y*NT: } 1.76^{* * *} \\
\text { NT*Educ: }-26.35^{* * *}\end{array}$ & \\
\hline Square variables & & $\begin{array}{c}\mathrm{Y}^{2}: 0.09^{*} \\
\text { Educ }^{2}: 0.768^{* * *}\end{array}$ & \\
\hline $\begin{array}{l}\text { Additional } \\
\text { statistics }\end{array}$ & $\begin{array}{c}\mathrm{R}^{2}=0.697, \text { Adj. } \\
\mathrm{R}^{2}=0.669, \\
\text { Prob(F-stat.) }=0.000\end{array}$ & $\begin{array}{c}\mathrm{R}^{2}=0.774, \text { Adj. } \\
\mathrm{R}^{2}=0.744, \\
\text { Prob(F-stat. })=0.000\end{array}$ & $\begin{array}{c}\mathrm{R}^{2}=0.624, \text { Adj. } \\
\mathrm{R}^{2}=0.5894, \\
\text { Prob(F-stat.) }=0.000\end{array}$ \\
\hline $\begin{array}{l}\text { Diagnostic test } \\
\text { statistics }\end{array}$ & $\begin{array}{c}\text { BPG Heteroskedacticity: } \\
\text { 9.946*; JB Normality: } \\
\text { 3.18; Ramsey RESET: } \\
\text { 6.931** }\end{array}$ & $\begin{array}{c}\text { BPG Heteroskedacticity: } \\
\text { 9.982; JB } \\
\text { Normality:5.307* }\end{array}$ & $\begin{array}{c}\text { BPG Heteroskedacticity: } \\
\text { 9.319*; JB Normality: } \\
0.444 \text {; Ramsey RESET: } \\
1.049\end{array}$ \\
\hline
\end{tabular}

Note: $* * *$ and $* * *$ shows significance at $10 \%, 5 \%$ and $1 \%$ levels.

Source: Authors own calculations by using Stata.

According to Table 4 results, there are non-linear relationships between government effectiveness and its determinants ( $p$-value of Ramsey RESET test is lower than $5 \%$ ). Then the regression model with the non-linear factors can be interpreted as (i) holding all other variables fixed, every 1 standard deviation increase of non-tradition leads to a 1.865 points increase in government effectiveness, (ii) there is increasing effects with increasing rate of both economic development and education on government. On the other hand, Table 4 shows that there are linear relationships between political stability and its determinants. Then the coefficients can be interpreted as (a) each of independent variables except urbanization has increasing effect on government effectiveness. Holding all other variables fixed, 1 unit increase in economic development, non-tradition, openness and education increases government effectiveness by $0.622,1.467,0.182$ and 1.91 standard deviation(s). 
Indicators of institutional quality, 2010-2014

Table 5

\begin{tabular}{|c|c|c|c|c|}
\hline & \multicolumn{4}{|c|}{ Dependent Variable } \\
\hline & \multicolumn{2}{|c|}{ Regulation } & \multicolumn{2}{|r|}{ Voice } \\
\hline \multirow{6}{*}{$\begin{array}{l}\text { Linear } \\
\text { variables }\end{array}$} & C: $-5.135^{* *}$ & $164.973 * *$ & -2.85 & -1.145 \\
\hline & $\mathrm{Y}: 0.678^{* * *}$ & & $0.5782 * * *$ & $-8.648(0.1223)$ \\
\hline & NT: $1.538^{*}$ & $\begin{array}{c}140.566 * * * \\
{\left[1.82^{* *}\right]}\end{array}$ & 1.593 & $106.35^{* *}[0.941]$ \\
\hline & Open: $0.24 *$ & & -0.173 & \\
\hline & Urban: $-0.742 *$ & & -0.426 & $11.961 * * *[-0.4302]$ \\
\hline & Educ: 0.111 & $\begin{array}{c}-85.223^{* *} \\
{[-97.28]}\end{array}$ & -0.1525 & \\
\hline $\begin{array}{l}\text { Interaction } \\
\text { variables }\end{array}$ & & $\begin{array}{c}\text { Y*NT: } 1.803^{* * *} \\
\text { NT*Open: } \\
0.7392^{* *} \\
\text { NT*Educ: } \\
-35.26^{* * *}\end{array}$ & & $\begin{array}{c}\text { Y*NT: } 2.90 * * * \\
\text { Y*Urban: }-0.357 \\
(0.163) \\
\text { Y*Educ: } 2.151^{*} \\
\text { NT*Open: } 2.934^{* *} \\
\text { NT*Educ: }-32.264 * * * \\
\text { Open*Urban: }-2.09 * * * \\
\text { Open*Educ: } 1.715 * * *\end{array}$ \\
\hline $\begin{array}{l}\text { Square } \\
\text { variables }\end{array}$ & & Educ $^{2}: 10.765^{* *}$ & & $\begin{array}{c}\text { Educ }^{2}:-2.0022(0.147) \\
{\left[-1.276^{* *}\right]}\end{array}$ \\
\hline $\begin{array}{l}\text { Additional } \\
\text { statistics }\end{array}$ & $\begin{array}{c}\mathrm{R}^{2}=0.598, \text { Adj. } \\
\mathrm{R}^{2}=0.5603 \\
\text { Prob(F-stat.) }= \\
0.000\end{array}$ & $\begin{array}{c}\mathrm{R}^{2}=0.677 \\
\text { Adj. } \mathrm{R}^{2}=0.641, \\
\text { Prob(F-stat. })= \\
0.000\end{array}$ & $\begin{array}{c}\mathrm{R}^{2}=0.4632, \text { Adj. } \\
\mathrm{R}^{2}=0.4135, \\
\text { Prob(F-stat.) }= \\
0.000\end{array}$ & $\begin{array}{c}\mathrm{R}^{2}=0.691, \mathrm{Adj} \\
\mathrm{R}^{2}=0.62 \\
\text { Prob(F-stat.) }=0.000\end{array}$ \\
\hline $\begin{array}{l}\text { Diagnostic } \\
\text { test statistics }\end{array}$ & $\begin{array}{c}\text { BPG Heteroske- } \\
\text { dacticity: } 9.654^{*} \text {; } \\
\text { JB Normality: } \\
\text { 5.184*; Ramsey } \\
\text { RESET: } 3.402^{*}\end{array}$ & $\begin{array}{c}\text { BPG Heteroske- } \\
\text { dacticity: } \\
14.75^{* *} ; \\
\text { JB Normality: } \\
4.634^{*} \\
\end{array}$ & $\begin{array}{c}\text { BPG Heteroske- } \\
\text { dacticity: } 2.683 ; \\
\text { JB Normality: } \\
\text { 3.634; Ramsey } \\
\text { RESET: } 2.98^{*}\end{array}$ & $\begin{array}{l}\text { BPG Heteroske- } \\
\text { dacticity: } 12.536 \text {; } \\
\text { JB Normality: } 0.583\end{array}$ \\
\hline
\end{tabular}

Note: $* * *$ and $* * *$ shows significance at $10 \%, 5 \%$ and $1 \%$ levels.

Source: Authors own calculations by using Stata.

According to Table 5 results, there are non-linear relationships between regulation quality and its determinants at $10 \%$ level. So, there is not much difference between linear and non-linear model results. Then the regression model with non-linear factors can be interpreted as (i) holding all other variables fixed, every 1 standard deviation increase of non-tradition leads to a 1.82 points increase in regulation quality, (ii) there is decreasing effects with increasing rate of education on regulation quality is the case; that is till $\log ($ educ $)=97.28$ / $(2 * 10.765)=4.51835$ or optimal literacy rate of $91.684 \%$. About $47 / 60 * 100=$ $78.333 \%$ of values of literacy rate lie above $91.684 \%$. then for majority of countries, there is a convex relationship between education level and regulation quality. Also, Table 5 shows that there are non-linear relationships between voice/ accountability and its determinants. Then the coefficients can be interpreted as (a) 
holding all other variables fixed, urbanization has diminishing effects on voice/ accountability, which is not consistent with former hypotheses, (b) holding all other variables fixed, non-tradition has positive effect on voice/accountability; every 1 standard deviation increase of non-tradition leads to an increase of 0.941 standard deviation in voice/accountability, (c) education has forever diminishing effects on voice/accountability, which is not consistent with theories.

\section{CONCLUSION}

In this study, the OLS models are employed in order to understand the key factors of institutional differences among countries in the period of 2010-2014. The empirical model results show that (i) non-tradition is a reliable significant variable with positive contributions on six institutional quality variables, (ii) urbanization has unexpected negative effects on some institutional quality indicators like rule of law, political stability and voice/accountability. However, it has meaningful contribution to control of corruption in the countries, (iii) economic development have increasing impacts on the majority of the institutional quality variables. (iv) while education has positive effects on government effectiveness, political stability and regulation quality, it has negative unexpected impacts on rule of law and voice/accountability, (v) openness has only effects on corruption and political stability, (vi) there are non-linear relationships between dependent variable(s) and independent variables rather than linear relationships. This in turn lead the goodness of fit to be higher, (vii) OLS estimators are BLUE. By using model results, it can be recommended that (a) NT and economic growth can be thought as the reliable factors to better off institutional quality and thus economic actors in the countries, (b) education can be good instrument for improving government effectiveness, political stability and regulation quality.

A non-traditional society tends to emphasize values 'independence and determination' in children rather than 'religious faith and obedience' (Inglehart, Baker, 2000). Independence and determination are among the key elements of achievements and development. On the other hand, when traditional values award being religious, loyalty, obedience, and national pride etc., this could prevent successful progressing in terms of institutional quality. This should not, of course, be viewed as a 'criticism' of traditional values, but as a study of the influence of various traditional values on the quality of institutions. Different countries adopt different paths even though they are subjected to similar traditional values while holding economic development constant. The work carried out to analyze the underlying causes of institutional differences can be viewed as a contribution to the more recent literature. 


\section{REFERENCES}

Acemoglu D., Johnson S., Robinson J.A. Institutions as a Fundamental Cause of Long Run Growth. Handbook of Economic Growth. Edited by P. Aghion, S. Durlauf. Amsterdam: North-Holland, 2006, pp. 386-472.

Acemoglu D., Johnson S., Robinson J.A. Reversal of Fortune: Geography and Development in the Making of the Modern World Income Distribution. Quarterly Journal of Economics, 2002, vol. 117, issue 4, pp. 1231-1294. https://doi.org/10.1162/003355302320935025

Acemoglu D., Johnson S., Robinson J.A. The Colonial Origins of Comparative Development: An Empirical Investigation. American Economic Review, 2001, vol. 91, no. 5, pp. 1369-1401. https://doi.org/10.1257/aer.91.5.1369

Acemoglu D., Robinson J.A. Why Nations Fail: The Origins of Power, Prosperity and Poverty. New York: Crown Publishers, 2012, 571 p.

Alesina A., Angeletos G.-M. Fairness and Redistribution. American Economic Review, 2005, vol. 95, no. 4, pp. 960-980.

Alesina A., Giuliano P. Culture and Institutions. Journal of Economic Literature, 2015, vol. 53, no. 4, pp. 898-944. https://doi.org/10.1257/jel.53.4.898

Alesina A., Giuliano P. Family Ties. NBER. Working Paper No. 18966, 2013. Available at: https://www.nber.org/system/files/working_papers/w18966/w18966.pdf (accessed March 2021).

Alesina A., Giuliano P. The Power of the Family. NBER. Working Paper No. 13051, 2007, 52 p. Available at: https://www.nber.org/system/files/working_papers/w13051/w13051. pdf (accessed May 2021).

Alesina A., La Ferrara E. Who Trusts Others? Journal of Public Economics, 2002, vol. 85, issue 2, pp. 207-234. https://doi.org/10.1016/S0047-2727(01)00084-6

Algan Y., Cahuc P. Inherited Trust and Growth. American Economic Review, 2010, vol. 100, no. 5, pp. 2060-2092. https://doi.org/10.1257/aer.100.5.2060

Algan Y., Cahuc P. Trust, Growth and Happiness: New Evidence and Policy Implications. Handbook of Economic Growth. Edited by Ph. Aghion, S. Durlauf. Elsevier B.V., 2014, pp. 49-120. https://doi.org/10.1016/B978-0-444-53538-2.00002-2

Algan Y., Cahuc P., Sangnier M. Trust and the Welfare State: The Twin Peaks Curve. The Economic Journal, 2016, vol. 126, issue 593, pp. 861-883. https://doi.org/10.1111/ ecoj. 12278

Alonso J.A., Garcimartin C. The Determinants of Institutional Quality: More on the Debate. Journal of International Development, 2013, vol. 25, issue 2, pp. 206-226. https://doi. org/10.1002/jid.1710

Aoki M. Toward a Comparative Institutional Analysis. Cambridge: MIT Press, 2001, 467 p.

Bisin A., Verdier T. On the Joint Evolution of Culture and Institutions. NBER. Working Paper No. 23375, 2017, 67 p.

Boettke P.J., Coyne C.J., Leeson P.T. Institutional Stickiness and the New Development Economics. American Journal of Economics and Sociology, 2008, vol. 67, issue 2, pp. 331-358. https://doi.org/10.1111/j.1536-7150.2008.00573.x

Borisova E., Govorun A., Ivanov D. Social Capital and Support for the Welfare State in Russia. Post-Soviet Affairs, 2017, vol. 33, issue 5, pp. 411-429. http://dx.doi.org/10.10 80/1060586X.2017.1348588

Breuer J.B., McDermott J. Respect, Responsibility, and Development. Journal of Development Economics, 2013, vol. 105, pp. 36-47. https://doi.org/10.1016/j.jdeveco.2013.06.004

Cassar A., d'Adda G., Grosjean P. Institutional Quality, Culture, and Norms of Cooperation: Evidence from a Behavioral Field Experiment. Journal of Law and Economics, 2014, vol. 57, no. 3, pp. 821-863. http://doi.org/10.1086/678331 
Chang H. Institutions and Economic Development: Theory, Policy and History. Journal of Institutional Economics, 2011, vol. 7, issue 4, pp. 473-498. https://doi.org/10.1017/ S1744137410000378

Chong A., Zanforlin L. Law Tradition and Institutional Quality: Some Empirical Evidence. Journal of International Development, 2000, vol. 12, no. 8, pp. 1057-1068. https://doi. org/10.1002/jid.681

Djankov S., McLiesh C., Nenova T., Schleifer A. Who Owns the Media? NBER. Working Paper No. 8288, 2001, 49 p. Available at: https:/www.nber.org/system/files/working_ papers/w8288/w8288.pdf (accessed November 2020).

Galasso V., Profeta P. When the State Mirrors the Family: The Design of Pension Systems. CEPRA. Working Paper 1201, 2012, 57 p.

Glaeser E.L., La Porta R., López-de-Silanes F., Shleifer A. Do Institutions Cause Growth? Journal of Economic Growth, 2004, vol. 9, pp. 271-303. https://doi.org/10.1023/ B:JOEG.0000038933.16398.ed

Gorodnichenko Y., Roland G. Culture, Institutions, and Democratization. NBER. Working Paper 21117, 2015, 42 p. Available at: https:/www.nber.org/system/files/working_papers/w21117/w21117.pdf (accessed December 2020).

Gorodnichenko Y., Roland G. Culture, Institutions, and the Wealth of Nations. NBER. Working Paper 16368, 2010, 49 p. Available at: https://www.nber.org/system/files/working_papers/w16368/w16368.pdf (accessed November 2020).

Gorodnichenko Y., Roland G. Understanding the Individualism-Collectivism Cleavage and Its Effects: Lessons from Cultural Psychology. Institutions and Comparative Economic Development. Edited by M. Aoki, T. Kuran, G. Roland. London: Palgrave Macmillan, 2012, pp. 213-236. https://doi.org/10.1057/9781137034014 12

Guiso L., Sapienza P., Zingales L. The Role of Social Capital in Financial Development. American Economic Revie, 2004, vol. 94, no. 3, pp. 526-556. https://doi. org/10.1257/0002828041464498

Guiso L., Sapienza P., ZingalesDoes L. Culture Affect Economic Outcomes? Journal of Economic Perspectives, 2006, vol. 20, no. 2, pp. 23-48. https://doi.org/10.1257/jep.20.2.23

Hofstede G. Culture's Consequences: Comparing Values, Behaviors, Institutions, and Organizations Across Nations. Sage Publications, 2001, 616 p.

Hofstede G., Hofstede G.J., Minkov M. Cultures and Organizations: Software of the Mind. New York: McGraw-Hill, 2010, 576 p.

Inglehart R. Modernization and Post-Modernization: Cultural, Economic, and Political Change in 43 Societies. Princeton: Princeton University Press, 1997, 454 p.

Inglehart R., Baker W.E. Modernization, Cultural Change, and the Persistence of Traditional Values. American Sociological Review, 2000, vol. 65, pp. 19-51. https://doi. $\operatorname{org} / 10.2307 / 2657288$

Islam R., Montenegro C.E. What Determines the Quality of Institutions. The World Bank. Policy Research Working Paper No. 2764, 2002, 31 p. Available at: https://openknowledge.worldbank.org/bitstream/handle/10986/15725/multi0page. pdf? sequence $=1$ \&isAllowed=y (accessed December 2020).

Jarque C.M., Bera A.K. Efficient Tests for Normality, Homoskedasticity and Serial Independence of Regression Residuals: Monte Carlo Evidence. Economic Letters, 1981, vol. 7, issue 4, pp. 313-318. https://doi.org/10.1016/0165-1765(81)90035-5

Kyriacou A. Individualism-Collectivism, Governance and Economic Development. MPRA. Paper No. 65151, 2015, 28 p. Available at: https://mpra.ub.uni-muenchen.de/65151/1/ MPRA_paper_65151.pdf (accessed November 2020).

La Porta R., Lopez-de-Silanes F., Shleifer A., Vishny R. The Quality of Goverment. The Journal of Law, Economics, and Organization, 1999, vol. 15, issue 1, pp. 222-279. https://doi.org/10.1093/jleo/15.1.222 
North D. Institutions, Institutional Change, and Economic Performance. Cambridge: Cambridge University Press, 1990, $152 \mathrm{p}$.

North D. Understanding the Process of Economic Change. Princeton; New York: Princeton University Press, 2005, 200 p.

Platteau, J.-P. Institutions, Social Norms, and Economic Development. Amsterdam: Harwood Academic Publishers, 2000, 384 p.

Rodrik D., Subramanian A., Trebbi F. Institutions Rule: The Primacy of Institutions over Geography and Integration in Economic Development. Journal of Economic Growth, 2004, vol. 9, pp. 131-165. https://doi.org/10.1023/B:JOEG.0000031425.72248.85

Roland G. Culture, Institutions and Development. UC Berkeley, CEPR and NBER, 2016a, 39 p. Available at: https://eml.berkeley.edu/ groland/pubs/Culturesurveyvf.pdf (accessed November 2019).

Roland G. Individualist and Collectivist Culture and their Economic Effects. Constraints and Driving Forces in Economic Systems: Studies in Honor of Janos Kornai. Edited by M. Rosta, B. Hámori. Cambridge Scholars Publishing, 2016b, pp. 31-50.

Roland G. Understanding Institutional Change: Fast-Moving and Slow-Moving Institutions. Studies in Comparative International Development, 2004, vol. 38, issue 4, pp. 109-131. https://doi.org/10.1007/BF02686330

Rose D.C. Why Culture Matters Most. American Economic Association. Boston, 2015, 15 p.

Schwartz S.H. A Theory of Cultural Values and Some Implications for Work. Applied Psychology, 1999, vol. 48, issue 1, pp. 23-47. https://doi.org/10.1111/j.1464-0597.1999. tb00047.x

Schwartz S.H. An Overview of the Schwartz Theory of Basic Values. Online Readings in Psychology and Culture, 2012, vol. 2, issue 1. http://dx.doi.org/10.9707/2307-0919.1116

Straub S. Empirical Determinats of Good Institutions: Do We Know Anything? Inter-American Development Bank. Research Deparment Working Paper No. 423, 2000, 50 p. Available at: https://publications.iadb.org/publications/english/document/Empirical-Determinants-of-Good-Institutions-Do-We-Know-Anything.pdf (accessed February 2020).

Tabellini G. Culture and Institutions: Economic Development in the Regions of Europe. Journal of the European Economic Association, 2010, vol. 8, issue 4, pp. 677-716. https://doi.org/10.1111/j.1542-4774.2010.tb00537.x

Tabellini G. Presidential Address Institutions and Culture. Journal of the European Economic Association, 2008, vol. 6, issue 2-3, pp. 255-294. https://doi.org/10.1162/ JEEA.2008.6.2-3.255

Weber M. The Protestant Ethic and the Spirit of Capitalism. London: Routledge, 1930, 320 p. https://doi.org/10.4324/9780203995808

Wei S.J. Natural Openness and Good Goverment. The World Bank. Policy Research Working Paper No. 2411, 2000, 32 p. Available at: https://openknowledge.worldbank.org/ handle/10986/19796 (accessed February 2020).

Williamson C.R. Informal Institutions Rule: Institutional Arrangements and Economic Performance. Public Choice, 2009, vol. 139, issue 3, pp. 371-387. https://doi.org/10.1007/ s11127-009-9399-x

Wooldridge J.M. Introductory Econometrics: A Modern Approach. $6^{\text {th }}$ Edition. Boston: Cengage Learning, 2016, 912 p.

Поступила в редакцию / Submitted: 18.05.2021

Одобрена после рецензирования / Approved after reviewing: 09.08.2021

Принята к публикации / Accepted for publication: 07.09.2021

Доступно онлайн / Available online: 30.09.2021 